\title{
Yield and water use of a ryegrass/white clover sward under different nitrogen and irrigation regimes
}

\author{
A.D. BLACK and H.M. MURDOCH \\ Department of Agricultural Sciences, Lincoln University, Lincoln 7647, Christchurch \\ alistair.black@lincoln.ac.nz
}

\begin{abstract}
We investigated how $\mathrm{N}$ availability affected the wateruse efficiency (WUE) of a perennial ryegrass/white clover sward under different soil moisture regimes at Lincoln. Four combinations of $\pm \mathrm{N}$ fertiliser and \pm irrigation (I) were applied to plots rotationally grazed by sheep, and WUE (yield/water used) was measured from August 2011 to May 2013. The $+\mathrm{N}$ swards had a higher annual WUE than -N swards (27 vs $19 \mathrm{~kg} \mathrm{DM} /$ $\mathrm{ha} / \mathrm{mm}$ ) due to greater yields for the same amount of water used. This was associated with higher $\mathrm{N}$ contents in the $+\mathrm{N}$ grass herbage. The $\mathrm{N}$ response of WUE was consistent across soil moisture regimes and for most of each year. Irrigation did not affect annual WUE because the + I swards yielded more herbage but used more water than the - I swards. The results suggest that high WUE can be achieved by strategic applications of $\mathrm{N}$ fertiliser, use of pure legume swards, and through management that encourages clover growth in grass/clover swards.

Keywords: dryland, Lolium perenne, Trifolium repens, water-use efficiency
\end{abstract}

\section{Introduction}

Pasture growth in New Zealand is often limited by inadequate rainfall, so it is important to utilise available water as efficiently as possible. Water-use efficiency (WUE) can be defined as the total yield of a sward divided by the total amount of water used. In Canterbury, Martin et al. (2006) estimated the annual WUE of irrigated ryegrass (Lolium perenne L.)/white clover (Trifolium repens L.) pastures at $20 \mathrm{~kg} \mathrm{DM} / \mathrm{ha}$ per mm of water used. For a dryland ryegrass pasture on a stony Lismore soil, Moot et al. (2008) reported an annual WUE of $16 \mathrm{~kg} \mathrm{DM} / \mathrm{ha} / \mathrm{mm}$, and seasonal WUE values which decreased from $22 \mathrm{~kg} D M / h a / m m$ in spring to $3 \mathrm{~kg} \mathrm{DM} / \mathrm{ha} / \mathrm{mm}$ over summer. During spring, when moisture was not limiting, they found legume and grass/legume swards used water more efficiently than pure grass swards. A pure cocksfoot (Dactylis glomerata L.) sward reached an annual WUE of $38 \mathrm{~kg}$ $\mathrm{DM} / \mathrm{ha} / \mathrm{mm}$ when fertilised with luxurious amounts of $\mathrm{N}$, but it was only $17 \mathrm{~kg} \mathrm{DM} / \mathrm{ha} / \mathrm{mm}$ when unfertilised (Mills 2007; Moot et al. 2008). These results were ascribed to higher concentrations of $\mathrm{N}$ in the herbage, which increased the expansion of the leaf canopy and the photosynthetic capacity of leaves per unit of water used (Peri et al. 2002).

The objective of this study was to investigate how $\mathrm{N}$ fertiliser and irrigation affect the WUE of a perennial ryegrass/white clover sward. Specific questions were: 1) How does WUE respond to N availability? 2) Does the response depend upon water supply? 3) Is the response consistent over time? 4) How can farmers use legumes and $\mathrm{N}$ fertiliser to maximise WUE?

\section{Materials and methods}

Four combinations of $\pm \mathrm{N}$ fertiliser and \pm irrigation were applied to $5 \times 6 \mathrm{~m}$ plots of ryegrass/white clover at Iverson Field (I8), Lincoln University, according to a $2^{2}$ factorial randomised complete block design with four replicates. The plots were measured over 15 consecutive regrowth intervals between 5 August 2011 and 1 May 2013.

The site was flat and the soil was a deep $(>2 \mathrm{~m})$ Wakanui silt loam with $\mathrm{pH} 5.9$, Olsen $\mathrm{P} 22 \mathrm{mg} / \mathrm{L}$, $\mathrm{Mg} 1.02 \mathrm{me} / 100 \mathrm{~g}, \mathrm{~K} 0.9 \mathrm{me} / 100 \mathrm{~g}$ and $\mathrm{SO}_{4}-\mathrm{S} 3 \mathrm{mg} /$ $\mathrm{kg}$. The sward was sown on 7 January 2011 as a mix of 'Samson' AR37 perennial ryegrass $(8 \mathrm{~kg} / \mathrm{ha})$ and 'Tribute' white clover ( $4 \mathrm{~kg} / \mathrm{ha}$ ). It was grazed by sheep whenever the ryegrass had formed three new leaves per tiller (Fulkerson \& Donaghy 2001), to a residual height of 4-5 cm, to minimise the impact of grazing on regrowth. Sufficient sheep were used to graze the plots within 3-5 days, and the residual was trimmed to 4-5 $\mathrm{cm}$ when necessary using a lawn mower.

The $\mathrm{N}$ fertiliser was urea $(46 \% \mathrm{~N})$ applied at $50 \mathrm{~kg}$ $\mathrm{N} / \mathrm{ha}$ immediately after each grazing. Irrigation water was applied to the $+\mathrm{I}$ plots when their soil moisture content (SMC) to $0.5 \mathrm{~m}$ depth was $20-25 \%$, at $25 \mathrm{~mm} / \mathrm{h}$ through a system of sprinkler hoses. The SMC of the site at field capacity was about $35 \%$ and at permanent wilting point it was about $8 \%$ (Brown 2004).

\section{Measurements}

The water use and yield of each plot were observed 86 times over the 21 months, normally at 1-2 week intervals, to see how any differences between treatments changed over time. This gave 1360 observations in total. 


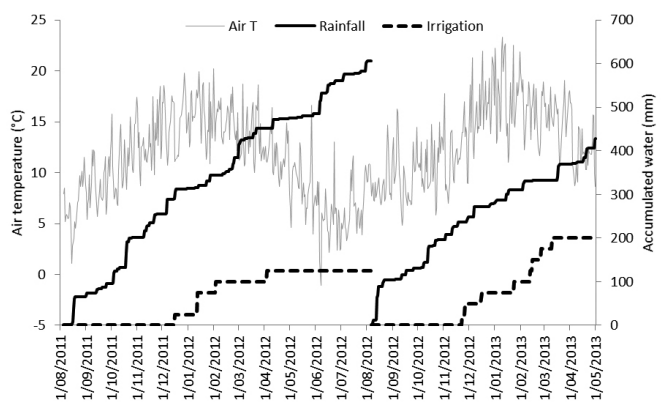

Figure 1 Daily mean air temperature, rainfall and irrigation applied to the ryegrass/white clover sward at Lincoln between 5 August 2011 and 1 May 2013.

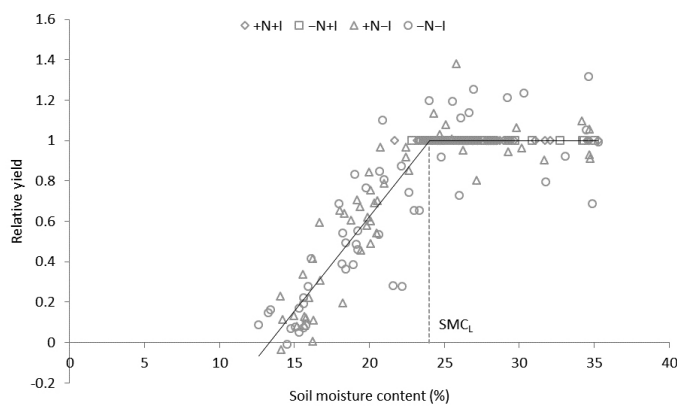

Figure 3 Relationship between the relative yield and soil moisture content (SMC) of a ryegrass/white clover sward treated with $\pm \mathrm{N}$ fertiliser and \pm irrigation (I) at Lincoln. The split-line model was $y=0.094 x$ below $24 \%\left(\mathrm{SMC}_{\perp}\right)$ and $y=1$ above $24 \%\left(\mathrm{R}^{2}=0.86\right)$.

The amount of water used since the previous measurement (i), including during grazing, was calculated as $\mathrm{R}+\mathrm{I}-(\mathrm{SMC}-\mathrm{SMCi})$, where $\mathrm{R}$ is rainfall and $\mathrm{I}$ is irrigation. SMC was measured using a Time Domain Reflectometer (Trace System, Soil Moisture Equipment, USA) with probes installed to 0.5 $\mathrm{m}$ depth. Rainfall data were obtained from Broadfields meteorological station which is $2 \mathrm{~km}$ north of Lincoln University (Figure 1). Air temperature was recorded on site at hourly intervals using a $\mathrm{HOBO}$ data logger.

Yield was the change in herbage mass (HM) since the previous measurement, and assumed zero during grazing. HM was measured using a Jenquip rising plate meter (RPM) by taking 10 readings/plot and converting the average RPM values to estimates of HM using calibration equations. To calibrate the RPM, on each measurement date a representative $0.2 \mathrm{~m}^{2}$ quadrat of herbage per plot was measured with the RPM (2 readings/quadrat), clipped to $1-2 \mathrm{~cm}$ above ground using battery powered sheep shears, and dried at $65^{\circ} \mathrm{C}$ to determine the quadrat $\mathrm{HM}$. A subsample (about $50 \mathrm{~g}$ ) was separated into grass and clover before drying and the proportion of clover was multiplied by the HM of

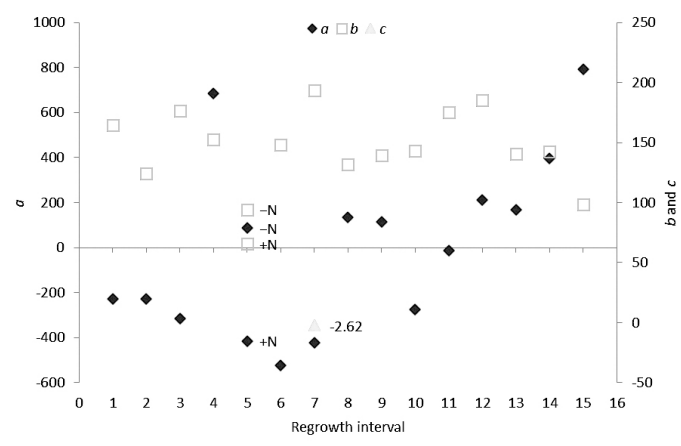

Figure 2 Coefficients of calibration equations for a rising plate meter (RPM) used to estimate the herbage mass of a ryegrass/white clover sward at Lincoln, over 15 consecutive regrowth intervals between 5 August 2011 and 1 May 2013. Normally, calibrations were linear models not affected by $\mathrm{N}$ fertiliser and irrigation $\left(y=a+b^{*} x\right.$ where $y$ is herbage mass and $x$ is RPM reading). Regrowth 7 required a quadratic model $\left(y=a+b^{*} x+c^{*} x^{2}\right)$ and for regrowth 5 the linear model was affected by $\mathrm{N}$ $\left(y_{-N}=a_{-N}+b_{-N}{ }^{*} x\right.$ and $\left.y_{+N}=\left[a_{-N}+a_{+N}\right]+\left[b_{-N}+b_{+N}\right]^{*} x\right)$.

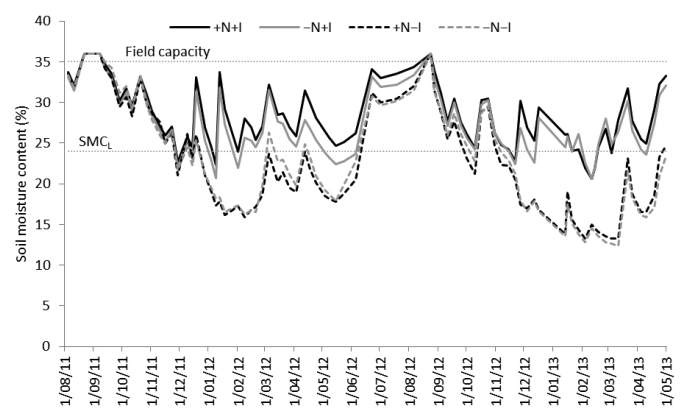

Figure 4 Influence of $\mathrm{N}$ fertiliser and irrigation (I) on soil moisture content to $0.5 \mathrm{~m}$ depth below a ryegrass/ white clover sward at Lincoln between 5 August 2011 and 1 May 2013 (maximum SEM=1.8). SMC is the critical limiting soil moisture content.

the plot (estimated with the RPM) to determine clover $\mathrm{HM}$ and then clover yield. Weeds were always less than $5 \%$ of HM.

Pre-grazing samples of ryegrass, white clover and "mixed" grass/clover herbage were retained to determine $\mathrm{N}$ content by near infrared reflectance spectroscopy.

\section{Data analysis}

For the RPM calibrations we fitted a linear regression model to the quadrat data of HM and RPM for each regrowth interval, and tested whether $\mathrm{N}$ fertiliser and irrigation affected the calibrations. Normally the linear models were good fits $\left(0.53<\mathrm{R}^{2}<0.94\right)$ and not affected by $\mathrm{N}$ fertiliser and irrigation (Figure 2). Regrowth 7 required a quadratic model $\left(\mathrm{R}^{2}=0.69\right)$ and for regrowth 5 the linear model was affected by $\mathrm{N}(\mathrm{P}<0.001)$. 
The point when SMC started to limit yield $\left(\mathrm{SMC}_{\mathrm{L}}\right)$ was determined from the relationship between relative yield and average SMC, which were calculated for each plot per regrowth interval. The relative yield of a plot was its yield divided by the yield of the $+\mathrm{I}$ plot in the same replicate and $\mathrm{N}$ level. The function was described by a split-line regression model with its second line forced horizontal, and $\mathrm{SMC}_{\mathrm{L}}$ was the point when relative yield reached 1 .

To test for treatment effects on WUE over time we plotted the accumulated yields against accumulated water use for each season. The graph showed the rate of increase of yield with water use (i.e., WUE) to change at one point in each season. It also showed the variation in the data increased as yield and water use increased. Therefore, we fitted a split-line regression model for each plot $\left(0.976<\mathrm{R}^{2}<0.997\right)$ to quantify WUE and when WUE changed. We also plotted accumulated clover yields against water use for each treatment and season.

Significant $(\alpha=0.05)$ treatment effects and their interaction on annual yields, annual water use, WUE and herbage $\mathrm{N}$ were tested by ANOVA. All analyses were done in Genstat 14 software.

\section{Results}

The $\mathrm{SMC}_{\mathrm{L}}$ was $24 \%$ and the rate of decrease of relative yield with $\mathrm{SMC}$ below the $\mathrm{SMC}_{\mathrm{L}}$ was 0.094 for every $1 \%$ change (Figure 3 ). Irrigation prevented SMC from decreasing below the $\mathrm{SMC}_{\mathrm{L}}$ for the majority of both seasons, although it was less than $24 \%$ for about 20 days in February 2013 (Figure 4). Without irrigation, $\mathrm{SMC}$ was below the $\mathrm{SMC}_{\mathrm{L}}$ for long periods from midDecember 2011 to early June 2012 and from midNovember 2012 to early May 2013. SMC was not affected by $\mathrm{N}$ fertiliser.

In 2011/12 the $+\mathrm{N}$ swards yielded $6.6 \mathrm{t} \mathrm{DM} /$ ha more biomass than $-\mathrm{N}$ swards $(\mathrm{P}<0.001)$ for the same amount of water used (Figure 5). This result was consistent across irrigation levels despite the $+\mathrm{I}$ swards producing $3.1 \mathrm{t} \mathrm{DM} /$ ha more than $-\mathrm{I}$ swards $(\mathrm{P}<0.001)$ after 114 $\mathrm{mm}$ of additional water use $(\mathrm{P}<0.001)$. WUE was $11 \mathrm{~kg}$ $\mathrm{DM} / \mathrm{ha} / \mathrm{mm}$ higher for $+\mathrm{N}$ than $-\mathrm{N}$ swards $(\mathrm{P}<0.001)$ between 5 August and April, with $623 \mathrm{~mm}$ used by the $+\mathrm{I}$ swards compared with $522 \mathrm{~mm}$ by the $-\mathrm{I}$ swards $(\mathrm{P}<0.001)$ (Figure 5 and Table 1). WUE then decreased but remained $9 \mathrm{~kg} \mathrm{DM} / \mathrm{ha} / \mathrm{mm}$ higher for $+\mathrm{N}$ swards over winter until 6 August 2012.

In 2012/13 the $+\mathrm{N}$ swards yielded $3.3 \mathrm{t} \mathrm{DM} /$ ha more than the $-\mathrm{N}$ swards $(\mathrm{P}<0.001)$ for the same water use, and the $+\mathrm{I}$ swards yielded $4.4 \mathrm{t} \mathrm{DM} /$ ha more than $-\mathrm{I}$ swards $(\mathrm{P}<0.001)$ for an additional $157 \mathrm{~mm}$ of water used $(\mathrm{P}<0.001)$ (Figure 5). In this season WUE was 8 $\mathrm{kg} \mathrm{DM} / \mathrm{ha} / \mathrm{mm}$ higher for $+\mathrm{N}$ than $-\mathrm{N}$ swards $(\mathrm{P}<0.001)$ between 7 August and November-December, with 251 $\mathrm{mm}$ used by the $+\mathrm{N}$ swards compared with 166-212 $\mathrm{mm}$ by the $-\mathrm{N}$ swards $(\mathrm{P}<0.05)$ (Figure 5 and Table 1). WUE then decreased over summer-autumn with no effect of $\mathrm{N}$, but irrigation increased it by $12 \mathrm{~kg} \mathrm{DM} / \mathrm{ha} /$ $\mathrm{mm}(\mathrm{P}<0.001)$.

In 2011/12 the annual clover yield doubled in response to irrigation, but halved in response to $\mathrm{N}$ fertiliser (Figure 6). Clover yield was not affected by $\mathrm{N}$ and irrigation for the first $310 \mathrm{~mm}$ of water used to 29 November. From then to 27 March the $-\mathrm{N}$ plots accumulated 2.5 times as much clover as the $+\mathrm{N}$ plots for the same water use, and the $+\mathrm{I}$ plots accumulated almost three times as much clover as the -I plots for an additional $80 \mathrm{~mm}$ of water used. Any further changes in clover yield over autumn and winter were small.

In 2012/13 the effect of irrigation on annual clover yield $(+770 \mathrm{~kg} \mathrm{DM} / \mathrm{ha})$ was not significant. The $-\mathrm{N}$ plots accumulated 6.5 times as much clover as the $+\mathrm{N}$ plots for the same amount of water used and at a constant rate over most of the growing season (Figure 6).

Table 1 Influence of $\mathrm{N}$ fertiliser and irrigation (I) on the water-use efficiency of a ryegrass/white clover sward at Lincoln from 5 August 2011 to 6 August 2012 and from 7 August 2012 to 1 May 2013.

\begin{tabular}{|c|c|c|c|c|c|c|}
\hline \multirow[t]{2}{*}{ Treatment } & \multicolumn{3}{|c|}{ 2011/12 } & \multicolumn{3}{|c|}{$2012 / 13$} \\
\hline & 5 Aug - Mar-Apr* & Mar-Apr - 6 Aug & Annual & 7 Aug - Nov-Dec ${ }^{\dagger}$ & Nov-Dec-1 May & Annual \\
\hline & \multicolumn{6}{|c|}{$\mathrm{kg} \mathrm{DM} / \mathrm{ha} / \mathrm{mm}$ of water used } \\
\hline$+\mathrm{N}+\mathrm{I}$ & 33 & 12 & 28 & 35 & 21 & 27 \\
\hline$-\mathrm{N}+\mathrm{I}$ & 23 & 5 & 20 & 26 & 18 & 20 \\
\hline$+\mathrm{N}-\mathrm{I}$ & 32 & 16 & 29 & 36 & 8 & 25 \\
\hline$-\mathrm{N}-\mathrm{I}$ & 20 & 6 & 18 & 29 & 7 & 18 \\
\hline $\operatorname{SED}_{\mathrm{N} \times 1}$ & 1.7 & 1.7 & 1.4 & 1.4 & 1.4 & 1.5 \\
\hline $\mathrm{N}$ & $<0.001$ & $<0.001$ & $<0.001$ & $<0.001$ & NS & $<0.001$ \\
\hline I & NS & NS & NS & NS & $<0.001$ & NS \\
\hline $\mathrm{N} \times \mathrm{I}$ & NS & NS & NS & NS & NS & NS \\
\hline
\end{tabular}

The actual dates when water-use efficiency changed ranged from 27 March to 24 April $2012^{\star}$ and from 15 November to 4 December $2012^{\dagger}$ 

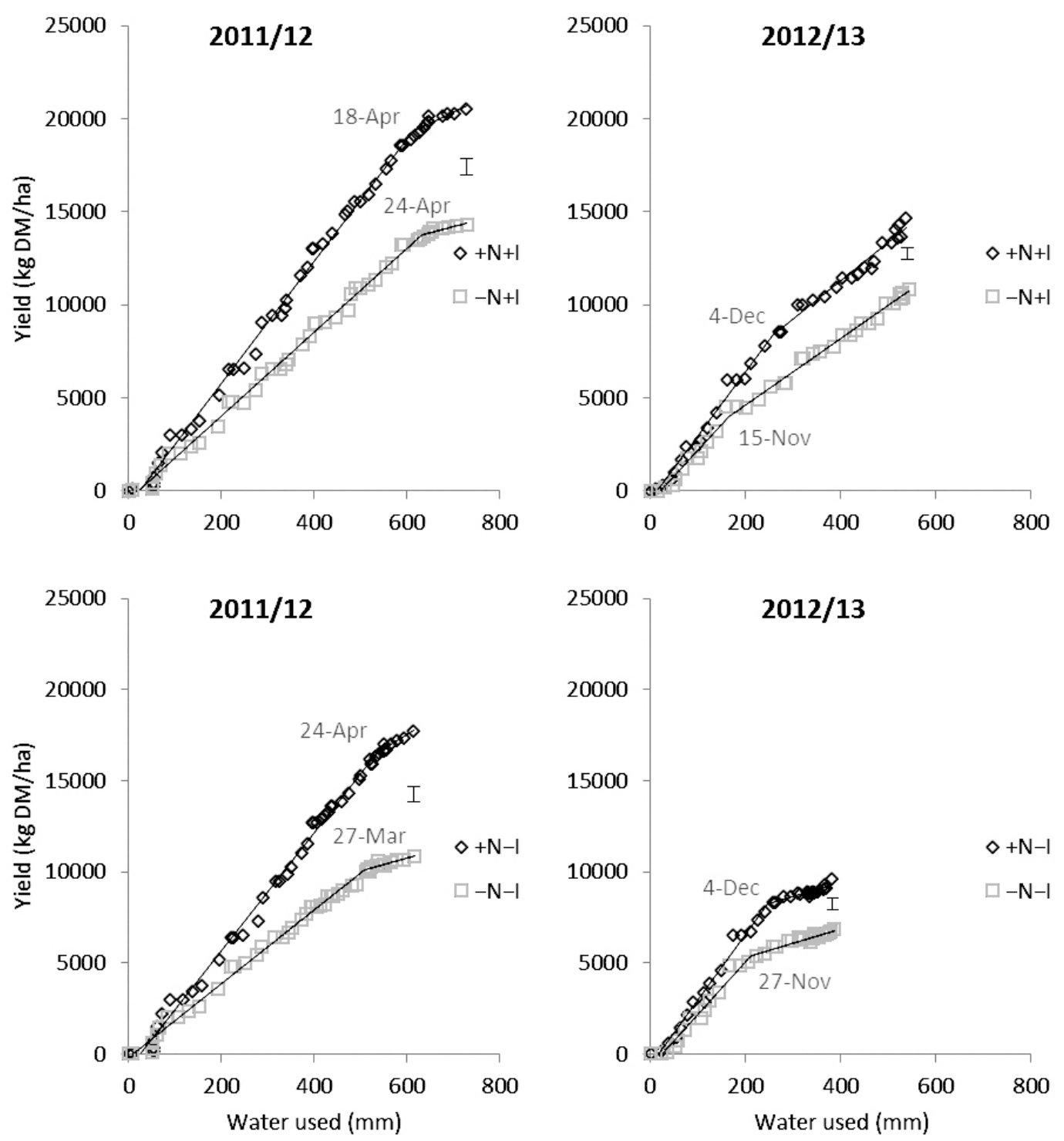

Figure 5 Influence of $\mathrm{N}$ fertiliser and irrigation (I) on the relationship between accumulated yield of total herbage and accumulated amount of water used for a ryegrass/white clover sward at Lincoln from 5 August 2011 to 6 August 2012 (left panels) and from 7 August 2012 to 1 May 2013 (right panels). Dates when water-use efficiency (slope of lines) changed are indicated. Bars $=\mathrm{SED}_{\mathrm{N} \times 1}$ for annual yield.

$\mathrm{N}$ fertiliser increased herbage $\mathrm{N}$ by $0.2-0.3 \%$ in mixture and ryegrass samples during 2011/12 and 2012/13 (Table 2). Irrigation had similar effects on herbage $\mathrm{N}$ in 2011/12 and for mixture material in $2012 / 13$. Clover had higher $N$ contents than ryegrass irrespective of $\mathrm{N}$ fertiliser ( $4.1 \%$ vs $2.9 \%$ ).

\section{Discussion}

This study has quantified a maximum annual WUE for a perennial ryegrass/white clover pasture at Lincoln of $29 \mathrm{~kg} \mathrm{DM} / \mathrm{ha}$ per $\mathrm{mm}$ of water used (Table 1). We achieved this and similar values $(25-28 \mathrm{~kg} \mathrm{DM} /$ $\mathrm{ha} / \mathrm{mm}$ ) with and without irrigation, by applying a luxurious amount of $\mathrm{N}$ fertiliser $(400 \mathrm{~kg} / \mathrm{ha} /$ year), and by ensuring that other factors such as grazing management and soil depth had minimal impacts on the yield of the pasture. In contrast, the annual WUE values obtained in the same pasture without $\mathrm{N}$ fertiliser 

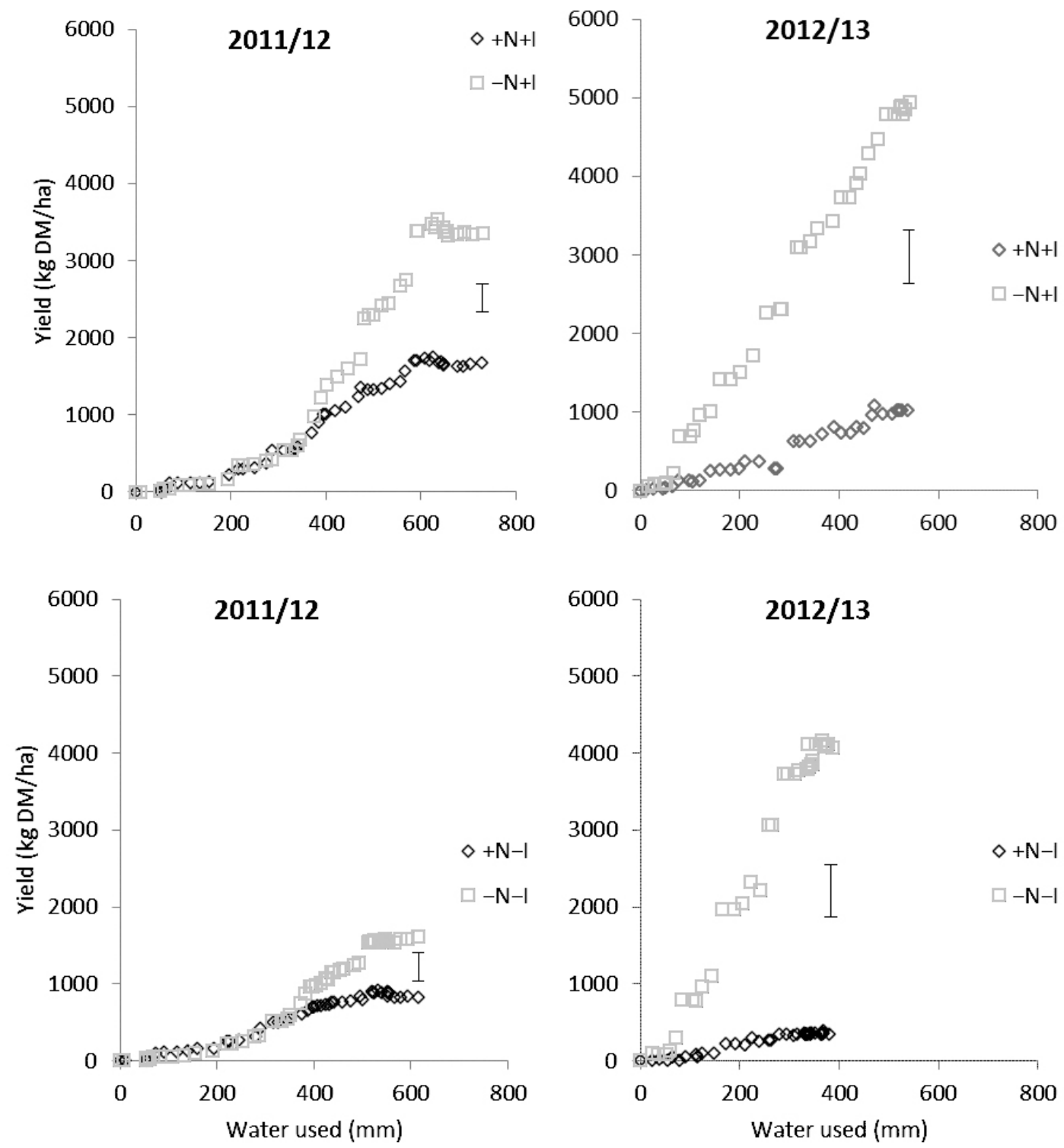

Figure 6 Influence of $\mathrm{N}$ fertiliser and irrigation (I) on the relationship between accumulated clover yield and accumulated water use for a ryegrass/white clover sward at Lincoln from 5 August 2011 to 6 August 2012 (left panels) and from 7 August 2012 to 1 May 2013 (right panels). Bars $=S_{E D} \times$ for annual clover yield.

were $61-69 \%$ of the maximum (18-20 $\mathrm{kg} \mathrm{DM} / \mathrm{ha} / \mathrm{mm})$. This management produced more clover (Figure 6), but the trade-off was lower annual total yields $(61-74 \%$ of $+\mathrm{N}$ swards) for the same amount of water used (Figure 5). In other words the amount of water used by the pasture did not depend upon its yield and botanical composition. This is because the water use of pastures and crops with complete ground cover is a function of water availability and atmospheric conditions rather than biological processes within the plant (Penman
1948). Therefore, at any given level of rainfall and irrigation, management strategies that can increase the productivity of pasture are also likely to utilise the supply of plant-available water more efficiently.

An adequate supply of $\mathrm{N}$ is essential for the leaf canopy expansion and photosynthesis of grass/clover swards (Black et al. 2009; Hay \& Porter 2006). The photosynthetic capacity of leaves and canopies of pastures and crops is closely linked to the concentration of $\mathrm{N}$ in the leaves (Fletcher et al. 2013; Peri et al. 2002). 
In our study the $\mathrm{N}$ fertiliser stimulated the growth of the ryegrass which increased its competitiveness towards the white clover, leading to increased total yields but less clover (Figures 5 and 6). The higher concentrations of $\mathrm{N}$ in the ryegrass and clover herbage with $\mathrm{N}$ fertiliser (Table 2) would have increased the overall canopy expansion (Mills et al. 2009) and ensured higher rates of leaf photosynthesis were obtained per unit of water used (Moot et al. 2008). Without $\mathrm{N}$ fertiliser the leaves of white clover would have occupied a higher proportion of the upper-most layers of the leaf canopy (Laidlaw \& Withers 1997) and maintained a high rate of leaf photosynthesis per $\mathrm{mm}$ of water used due to the positioning of these leaves and their $\mathrm{N}$ content. Although the amount of $\mathrm{N}$ derived from clover $\mathrm{N}$ fixation may have been higher in these swards (Ledgard et al. 2001), the leaf area expansion and photosynthetic capacity of the ryegrass would have decreased under limited $\mathrm{N}$ availability, resulting in the reductions in total yield and WUE.

The similar values of annual WUE for the two irrigation treatments (Table 1) can also be explained. Irrigation did not affect annual WUE because the + I swards yielded more total herbage and used more water than the -I swards (Figure 5). Irrigation increased clover yield in the first year, but only from $5 \%$ to $8 \%$ of total yield in the $+\mathrm{N}$ swards and from $15 \%$ to $24 \%$ in the $-\mathrm{N}$ swards (Figure 6). The lack of a significant effect of irrigation on clover yield in the second year was probably because the white clover in the $+\mathrm{N}$ swards was suppressed by the ryegrass to $4-7 \%$ of total yield, and in the $-\mathrm{N}$ swards the clover content had increased to $46-58 \%$ irrespective of irrigation. There was also evidence of higher $\mathrm{N}$ contents in the mixture and ryegrass herbage from the $+\mathrm{I}$ swards (Table 2), but this was not enough to cause a difference in annual WUE between irrigation regimes. Therefore the greater yields from the $+\mathrm{I}$ swards were likely to have been caused by increased light interception and similar rates of leaf photosynthesis per unit of water used (Mills et al. 2009). The consistent $\mathrm{N}$ effects on annual WUE across irrigation regimes shows the physiological responses to $\mathrm{N}$ were not modified by water availability for the majority of both growing seasons.

The WUE and its response to $\mathrm{N}$ fertiliser were consistent for long periods in each year (Figure 5 and Table 1). They decreased in March-April 2012 as temperature started to limit pasture growth, and some of the $134 \mathrm{~mm}$ of rainfall from then to 6 August (Figure 1) was probably lost as drainage below the 0.5 $\mathrm{m}$ depth of soil moisture measurement. From August to November-December 2012 the WUE and its N response were almost the same as the values for most of the first year. WUE then decreased to $19 \mathrm{~kg} \mathrm{DM} /$ $\mathrm{ha} / \mathrm{mm}$ for $+\mathrm{I}$ swards and only $7 \mathrm{~kg} \mathrm{DM} / \mathrm{ha} / \mathrm{mm}$ for $-\mathrm{I}$ swards because SMC started to limit growth (Figures 3 and 4). In the driest summer months, the irrigation was insufficient, and any rainfall was likely to be ineffective for the dried-off -I swards (Jamieson et al. 1995). The lack of $\mathrm{N}$ response in WUE after November was caused by the $-\mathrm{N}$ swards yielding more clover $(56 \%$ of total yield) than the $+\mathrm{N}$ swards $(6 \%$, Figure 6$)$ with higher herbage $\mathrm{N}$ than the ryegrass (Table 2).

The results from this study and Moot et al. (2008) highlight some important principles for maximising WUE on farms. On the same deep Wakanui silt loam soil, they reported an annual WUE of $40 \mathrm{~kg} \mathrm{DM} / \mathrm{ha} /$ $\mathrm{mm}$ for lucerne (Medicago sativa L.), $38 \mathrm{~kg} \mathrm{DM} / \mathrm{ha} /$ $\mathrm{mm}$ for cocksfoot with $\mathrm{N}$ fertiliser and $17 \mathrm{~kg} \mathrm{DM} / \mathrm{ha} /$ $\mathrm{mm}$ without $\mathrm{N}$. They measured spring WUE at $20 \mathrm{~kg}$ $\mathrm{DM} / \mathrm{ha} / \mathrm{mm}$ for perennial ryegrass/white clover and $13 \mathrm{~kg} \mathrm{DM} / \mathrm{ha} / \mathrm{mm}$ for perennial ryegrass, without $\mathrm{N}$ fertiliser. We can now include values for perennial ryegrass/white clover of $25-29 \mathrm{~kg} \mathrm{DM} / \mathrm{ha} / \mathrm{mm}$ with $\mathrm{N}$ fertiliser and $18-20 \mathrm{~kg} \mathrm{DM} / \mathrm{ha} / \mathrm{mm}$ without $\mathrm{N}$. The use of $\mathrm{N}$ fertiliser on grass-dominant swards can increase

Table 2 Influence of $\mathrm{N}$ fertiliser and irrigation (I) on the N content of ryegrass, white clover and "mixed" ryegrass/white clover herbage sampled from a ryegrass/white clover sward at Lincoln during 2011/12 and 2012/13 (averaged over regrowth intervals).

\begin{tabular}{|c|c|c|c|c|c|c|}
\hline \multirow[t]{2}{*}{ Treatment } & \multicolumn{3}{|c|}{ 2011/12 } & \multicolumn{3}{|c|}{$2012 / 13$} \\
\hline & Mixture & Grass & Clover & Mixture & Grass & Clover \\
\hline & \multicolumn{6}{|c|}{ Herbage N (\%) } \\
\hline$+\mathrm{N}+\mathrm{I}$ & 2.7 & 3.1 & \multirow{2}{*}{4.2} & 2.8 & 3.0 & \multirow{2}{*}{3.9} \\
\hline$+\mathrm{N}-\mathrm{I}$ & 2.5 & 2.8 & & 2.4 & 2.8 & \\
\hline$-\mathrm{N}+\mathrm{l}$ & 2.5 & 2.8 & \multirow{2}{*}{4.5} & 2.6 & 2.6 & \multirow{2}{*}{3.8} \\
\hline$-\mathrm{N}-\mathrm{I}$ & 2.2 & 2.6 & & 2.3 & 2.5 & \\
\hline $\operatorname{SED}_{\mathrm{N} \times 1}$ & 0.12 & 0.14 & $0.15^{\star}$ & 0.12 & 0.12 & $0.23^{*}$ \\
\hline $\mathrm{N}$ & $<0.01$ & $<0.01$ & $<0.05$ & $<0.05$ & $<0.001$ & NS \\
\hline I & $<0.01$ & $<0.01$ & - & $<0.001$ & NS & - \\
\hline
\end{tabular}

Clover was bulked across irrigation to obtain sufficient material for analysis; * $\mathrm{SED}_{\mathrm{N}}$; no interactions 
WUE if economically feasible. However, legumes are often more beneficial due to their $\mathrm{N}_{2}$ fixation ability, high forage quality, and also from a greenhouse gas perspective. High WUE can be achieved through the use of pure legume swards, such as lucerne, and grazing management that encourages perennial and annual clover growth in mixed swards (Brock \& Hay 1996; Smetham \& Dear 2003).

\section{Conclusions}

1. Perennial ryegrass/white clover had an annual WUE of $25-29 \mathrm{~kg} \mathrm{DM} / \mathrm{ha} / \mathrm{mm}$ with $400 \mathrm{~kg} \mathrm{~N} /$ ha/year compared with $18-20 \mathrm{~kg} \mathrm{DM} / \mathrm{ha} / \mathrm{mm}$ without $\mathrm{N}$ fertiliser. This was due to greater yields for the same amount of water used.

2. The WUE response to $\mathrm{N}$ fertiliser was robust across irrigated and un-irrigated regimes.

3. The response was consistent for most of each year, but decreased with low temperatures and drainage over winter, and with increased clover content and moisture stress over the dry 2012/2013 summer.

4. High WUE can be achieved on farms through the use of strategic $\mathrm{N}$ fertiliser, pure legume swards such as lucerne, and management that encourages clover growth in mixed swards.

\section{ACKNOWLEDGEMENTS}

We thank Sonia Patelli, Dan Dash, Keith Pollock, Venence Correia and Guillaume Duffet for their help on the experiment.

\section{REFERENCES}

Black, A.D.; Laidlaw, A.S.; Moot, D.J.; O'Kiely, P. 2009. Comparative growth and management of white and red clovers. Irish Journal of Agricultural and Food Research 33: 33-50.

Brock, J.L.; Hay, M.J.M. 1996. A review of the role of grazing management on the growth and performance of white clover cultivars in lowland New Zealand pastures. White clover: New Zealand's Competitive Edge. Agronomy Society of New Zealand Special Publication 11/Grassland Research and Practice Series 6: 65-70.

Brown, H.E. 2004. Understanding yield and water use of dryland forage crops in New Zealand. PhD Thesis. Lincoln University, New Zealand

Fletcher, A.L.; Johnstone, P.R.; Chakwizira, E.; Brown, H.E. 2013. Radiation capture and radiation use efficiency in response to $\mathrm{N}$ supply for crop species with contrasting canopies. Field Crops Research 150: 126-134.
Fulkerson, W.J.; Donaghy, D.J. 2001. Plant-soluble carbohydrate reserves and senescence - key criteria for developing an effective grazing management system for ryegrass-based pastures: a review. Australian Journal of Experimental Agriculture 41: 261-275.

Hay, R.J.M.; Porter, J.R. 2006. The physiology of crop yield. Blackwell Publishing Ltd, Oxford. 1-275 pp.

Jamieson, P.D.; Francis, G.S.; Wilson, D.R.; Martin, R.J. 1995. Effects of water deficit on evapotranspiration from barley. Agricultural and Forest Meteorology 76: 41-58.

Laidlaw, A.S.; Withers, J.A. 1997. Changes in contribution of white clover to canopy structure in perennial ryegrass/white clover swards in response to fertilizer. Grass and Forage Science 53: 48-54.

Ledgard, S.F.; Sprosen, M.S.; Penno, J.W.; Rajendram, G.S. 2001. Nitrogen fixation by white clover pastures grazed by dairy cows: Temporal varation and effects of nitrogen fertilization. Plant and Soil 229: 177-187.

Martin, R.J.; Thomas, S.M.; Stevens, D.R.; Zyskowski, R.F.; Moot, D.J.; Fraser, T.J. 2006. Improving water use efficiency on irrigated dairy farms in Canterbury. Proceedings of the New Zealand Grassland Association 68: 155-160.

Mills, A. 2007. Understanding constraints to cocksfoot (Dactylis glomerata L.) based pasture production. Ph.D thesis. Lincoln University, Canterbury.

Mills, A.; Moot, D.J.; Jamieson, P.D. 2009. Quantifying the effect of nitrogen on productivity of cocksfoot (Dactylis glomerata L.) pastures. European Journal of Agronomy 30: 63-69.

Moot, D.J.; Brown, H.E.; Pollock, K.M.; Mills, A. 2008. Yield and water use of temperate pastures in summer dry environments. Proceedings of the New Zealand Grassland Association 70: 51-57.

Penman, H.L. 1948. Natural evaporation from open water, bare soil and grass. Proceedings of the Royal Society Section A 108: 120-145.

Peri, P.L.; Moot, D.J.; McNeil, D.L.; Varella, A.C.; Lucas, R.J. 2002. Modelling net photosynthetic rate of field-grown cocksfoot leaves under different nitrogen, water and temperature regimes. Grass and Forage Science 57: 61-71.

Smetham, M.L.; Dear, B.S. 2003. The effect of continuous grazing on the seed production of Subterranean clover (Trifolium subterraneum). Legumes for Dryland Pastures. Grassland Research and Practice Series 11: 155-160. 
